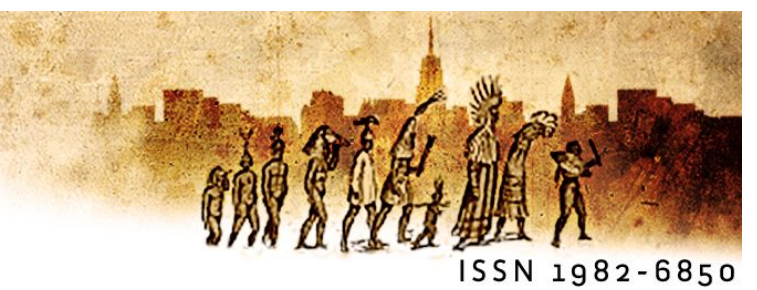

\title{
Nomes próprios como nomes de classes em textos ficcionais
}

\author{
Diogo Gurgeli (UFF)
}

Resumo: Neste trabalho, trato da ocorrência de nomes próprios em proposições metafóricas ou, de modo mais específico, de sua ocorrência como expressões de domínios-fonte em tais proposições. A partir de exemplos extraídos de grandes obras da literatura universal (Dom Casmurro, Fausto e $A$ Montanha Mágica), procuro estabelecer critérios claros de distinção entre a ocorrência de nomes próprios em metáforas analógicas e em metáforas categóricas (as quais produzem inclusões em classes). Assumo que tal distinção é de grande auxílio para uma elucidação do modo peculiar pelo qual metáforas literárias (e não somente metáforas filosóficas e científicas) podem assumir compromissos ontológicos. Se a distinção proposta procede, a sua negligência por parte da Teoria da Metáfora Conceitual desenvolvida nas últimas décadas por George Lakoff e seus colaboradores - mostra-se uma das razões para a insuficiência desta teoria no que diz respeito ao estudo de certos padrões metafóricos distintivos e idiossincráticos presentes em textos literários.

Palavras-chave: analogia; metáfora categórica; verdade.

\begin{abstract}
In this work, I deal with the occurrence of proper names in metaphorical propositions or, in a more specific way, I deal with the occurrence of them as expressions of source domains in such propositions. Considering examples extracted from major works of universal literature (Dom Casmurro, Faust and The Magic Mountain), I look for the establishment of clear criteria of distinction between the occurrence of proper names in analogical metaphors and in categorical metaphors (which produce class-inclusions). I assume that this distinction can be very helpful for the elucidation of the peculiar way by which literary metaphors (and not exclusively philosophical and scientific ones) could have ontological commitments. If I am not mistaken in making this claim, its negligence by the Conceptual Metaphor Theory - developed by George Lakoff and his partners in the last decades - appears as one of the reasons for the failure of this theory with regard to the study of certain distinctive and idiosyncratic metaphorical patterns that we find in literary texts.
\end{abstract}

Keywords: analogy; categorical metaphor; truth. 


\section{Introdução}

Já faz quase um século que I.A. Richards apresentou sua denúncia de que o rei da Retórica tradicional estava nu. Ou talvez seja mais acertado dizer que, nesse caso, a nudez real era a da rainha, da "rainha dos tropos", a metáfora. De todas as aberrações engendradas pela tropologia latina, certamente a mais perniciosa para o estudo filosófico do significado foi a concepção ornamental de metáfora. Assumiu-se como ponto pacífico que uma única e simplória fórmula (metaphora brevior est similitudo ${ }^{1}$ ) era suficiente para abarcar tudo o que se pode chamar de "metáfora". Com essa fórmula latina, estabeleceu-se que metáforas em nada podem contribuir para a descrição propriamente dita dos fatos, ficando relegadas à condição de meros recursos de embelezamento do discurso. De Richards para cá, muito corretivo tem sido gasto para desfazer o malfeito. Black, Ricoeur, Lakoff e Johnson, Bezuidenhout, Glucksberg, Cazeaux... muitas preciosas reformulações foram feitas sobre o assunto. Muitos bons autores têm defendido (ainda que por vias diversas) a existência do valor cognitivo próprio da metáfora, da referência metafórica, da verdade exposta via metáfora. Nesse meio tempo, houve, é claro, contundentes oposições à tese, dentre as quais destaco as de Donald Davidson, Paul Grice e Elisabeth Camp.

Diante da oportunidade de conjugar em um mesmo trabalho filosofia e crítica literária, gostaria de me inserir na referida disputa por uma via ainda pouco explorada. Entendo que a mesma pode ganhar um tempero especial no que lhe acrescentamos o seguinte ingrediente: nomes próprios ${ }^{2}$ também oferecem seus serviços às metáforas. Eis um dado que raramente se tem levado em conta quando o problema dos papéis semântico e cognitivo da metáfora está em pauta.

O presente trabalho convida a um exame do papel semântico desempenhado por nomes próprios quando ocorrem como domínio-fonte de sentenças metafóricas. $\mathrm{O}$ domínio-fonte, na concepção desenvolvida por George Lakoff a partir de Metaphors We Live By,

\footnotetext{
1 Trata-se de uma célebre passagem da obra Institutio Oratoria, de autoria do retor latino Quintiliano. De modo mais completo, temos: "in totum autem metaphora brevior est similitudo", ou seja, "no todo, porém, a metáfora é mais breve que a comparação" (OUINTILIANO, Institutio Oratoria, VIII, vi, 8-9).

2 Uso essa expressão em seu sentido mais ordinário, i.e., tenho em mente signos nominais que, de princípio, ao ocorrerem em sua forma singular, fazem referência a indivíduos singulares.
} 
é aquele conceito que fornece propriedades (dimensões) a partir das quais um outro conceito, o domínio-alvo, será considerado e compreendido. Meu ponto é que Lakoff e seus colaboradores no estabelecimento e perpetuação da Teoria da Metáfora Conceitual - responsáveis pelo estabelecimento de uma concepção que parece ser a mais influente em nossos dias - não têm estado muito atentos a uma certa peculiaridade desse modo de funcionamento dos nomes próprios em metáforas. Não raro, ao figurarem na posição de domínios-fonte, os nomes próprios parecem a um só tempo manter sua referência canônica a um indivíduo singular e desempenhar o papel de nomes de classes.

O texto que publiquei no número anterior desta revista apresentava a concepção experiencialista da metáfora desenvolvida por Lakoff e Johnson, aplicando sua descoberta da coerência sistemática de metáforas conceituais a certas composições de Guimarães Rosa. No presente trabalho, interessa-me fazer notar que, dentre as boas complementações e correções que essa teoria vem recebendo desde a década de 80, os trabalhos de Glucksberg, Keysar e Wee saltam aos olhos por se fundarem em evidências empíricas contundentes de que o uso de nomes próprios para expressar os domínios-fonte (ou "veículos", na terminologia de Richards) de metáforas nos permite ver de modo mais perspícuo o deslocamento categorial desempenhado por esses dispositivos de pensamento. Quero dizer: o caráter assertórico de um certo tipo de metáfora, sua afronta às categorias canonicamente estabelecidas e sua reivindicação de recategorização mostram-se em construções linguísticas como "Jeová é um Rothschild", "Todas as mulheres são Helenas", "Demjanjuk não é um Demjanjuk". Com uma só cajadada (a tematização da ocorrência de nomes próprios em metáforas) esses autores acertam muitos coelhos: afrontam a teoria tradicional do conceito, abalam o referencialismo extremado de Kripke, inviabilizam a abordagem parafrástica da metáfora proposta por Searle, atropelam a concepção estetizante da metáfora proposta por Davidson, e, de quebra, ainda dão aos entusiastas de Lakoff o que pensar sobre certos usos negligenciados de categorizações ad hoc. Abordarei tais questões desfrutando de exemplos da mais alta estirpe: Machado, Goethe, Mann, e que tais nos ofertam pérolas de seu grande estilo. E, a partir do exame desses exemplos, espero obter mais clareza sobre o que distingue a ocorrência de nomes próprios em metáforas analógicas e a ocorrência dos mesmos em metáforas categóricas. 
Ao final da exposição, proporei uma contribuição para o debate enfatizando o modo como o que chamarei aqui de "metáforas categóricas" podem proceder não apenas formando categorias superiores ou mais abrangentes do que aquelas de que os termos que a compõem habitualmente participam, mas também formando categorias inferiores ou mais sofisticadas e sutis do que as mesmas.

I.

Note-se, primeiramente, que não tenho o interesse de examinar, no trabalho que ora se inicia, as ocorrências de nomes próprios em proposições metafóricas de um modo geral. O enfoque que proponho recai sobre a ocorrência de nomes próprios como signos linguísticos de domínios-fonte e não como signos linguísticos de domínios-alvo. Desse modo, uma metáfora como "Sally é um bloco de gelo" (SEARLE, 2005, p.82) não será nosso objeto de estudo. Trataremos estritamente de metáforas como "Maria é a Gisele Bündchen da festa" e "Trieste não é uma Viena" (FREGE, 2009, p.121). Perceba-se que, em sentenças metafóricas na forma "a é b", i.e., em metáforas in praesentia, o(s) termo(s) que funcionam como domínios-fonte geralmente aparecem na posição $b$.

Apesar de não ser um pesquisador do tema da metáfora e de ter desenvolvido certas concepções (como a de "ideias associadas"3) que mais dificultam do que facilitam os estudos nessa área, Frege, em seu seminal artigo "Sobre Conceito e Objeto", fez um relevante apontamento sobre o estudo dos nomes próprios que reproduzo a seguir:

Não devemos nos deixar enganar pelo fato de a linguagem usar por vezes a mesma palavra ora como um nome próprio, ora como um termo conceitual. No exemplo acima ["Há apenas uma Viena"], o numeral indica que se trata do último caso. "Viena" é aqui um termo conceitual tal como "cidade imperial". Nesse sentido, pode-se dizer "Trieste não é uma Viena". (FREGE, 2009, p.120-121)

3 Ver como Frege distingue sentido, referência e ideias associadas em "Sobre sentido e referência" (FREGE, 2009, p.134). 
Esse apontamento de Frege me parece uma boa porta de entrada para nossa investigação na medida em que chama nossa atenção para o modo como um artigo pode determinar a operação desempenhada pelo nome na estrutura sentencial em que ocorre. O uso do artigo indefinido claramente demarca que, neste caso, o signo "Viena" é parte de um predicado cuja referência é um conceito e não um objeto singular. A partir desse apontamento, proponho que façamos uma distinção entre dois modelos de ocorrência de nomes próprios como signos dos domínios-fonte, a saber, o modelo analógico e o modelo categórico. Esses modelos não se excluem mutuamente e eles são dois em uma lista nem um pouco modesta de composições sentenciais que podem receber a alcunha de "metáforas"4.

Considerando as seguintes proposições metafóricas:

(1) "Maria é a Gisele Bündchen da festa"

(2) "Trieste não é uma Viena"

podemos estabelecer, por conta da presença do artigo indefinido em (2) e por sua ausência em (1), que a metáfora (1) é um caso de modelo analógico e que a metáfora (2) é um caso de modelo categórico. Mas certamente a ocorrência de um artigo indefinido é por demais contingente para ser um critério seguro de distinção entre espécies de metáfora. Com o intuito de averiguar se melhores critérios podem ser determinados, proponho examinarmos separadamente cada uma das espécies - ou do que se tende a ver como duas espécies distintas.

\section{Ocorrência de nomes próprios em analogias}

Na Poética, Aristóteles define a metáfora como "a transferência para uma coisa do nome de outra, ou do gênero para a espécie, ou da espécie para o gênero, ou da espécie de uma para o gênero de outra, ou por analogia" (ARISTÓTELES, 2005, 1457 b 6-9). Como se vê, a

\footnotetext{
4 Pense em quantas coisas diferentes designamos com o termo "metáfora". Atente às notórias diferenças que há entre sentenças metafóricas como "João é um porco" e "Discussão é guerra" - poderiam ambas ser chamadas de símiles abreviados? E o que dizer das diferenças entre "Julieta é o sol" e "Nenhum homem é uma ilha" mereceriam ambas o rótulo de falsidades patentes ou absurdos lógicos? Tampouco se deve afirmar que "Sally é um bloco de gelo" e "Ele vai me comer vivo" sejam, igualmente, predicações semanticamente impertinentes. E, ainda: se encontramos facilmente uma paráfrase para "Ele estava de cabeça quente", o mesmo não se aplica à metáfora filosófica "Denomino ideias as pálidas imagens dessas impressões (...)" (HUME, 2000, l, l, l, p.7).
} 
analogia é somente um entre diversos tipos de metáfora, de acordo com o Estagirita. A regra de cálculo da proporcionalidade fornecida pelo filósofo é a seguinte: $a: b:: c: d$ (a está para b como c está para d). Aplicando essa regra a "Maria é a Gisele Bündchen da festa", temos: Maria está para a festa como Gisele Bündchen está para o mundo. Trata-se de uma sentença cuja estrutura proporcional não temos dificuldade em estabelecer, tendo em vista que o termo b, o qual poderia estar implícito, aparece no corpo da sentença na forma da expressão "da festa". Tal expressão não tem apenas a função de facilitar a compreensão do proferimento, ela tem, sobretudo, a função de mitigar o caráter defectivo (impertinente) do mesmo. Nisso, o efeito produzido por essa expressão se assemelha ao efeito produzido pelas expressões "como", "nossa" e "com relação à beleza" nas proposições "Maria é como Gisele Bündchen", "Maria é a nossa Gisele Bündchen" ou "Maria é Gisele Bündchen, com relação à beleza".

Em todas as metáforas, não apenas nas metáforas analógicas, sempre ocorrem operações de destaque (highlighting) e ocultação (hiding) de aspectos relevantes, de modo que se constitua uma sistematização coerente de uma determinada experiência (LAKOFF; JOHNSON, 2003, p.10). Assim, nos casos de ocorrência de nomes próprios singulares em metáforas analógicas, o nome próprio singular, ao designar o objeto singular a que se refere, não o faz abarcando todas as propriedades (ou dimensões) desse objeto, mas tão somente aquelas que se fazem relevantes para a correspondência com o domínio-alvo. A seleção de aspectos do conceito do domínio-alvo é condicionada pela seleção de aspectos a partir da qual se compreende o domínio-fonte. O sistema de lugares-comuns (BLACK, 1955, p.287) habitualmente associado a "Gisele Bündchen" determina as características de Maria que vão ser realçadas e quais vão ficar em segundo plano. Note-se que, no caso de uma inversão da posição dos nomes, haveria uma alteração do sistema de lugares-comuns que estabelecem a correspondência - uma vez que o predominante (ou condicionante) seria agora aquele ligado ao nome "Maria".

Convenciona-se, hoje em dia, que símiles - sentenças que têm a forma "a é como b" - são formas de expressão literal, de modo que não caem sob a categoria das metáforas. Contudo, metáforas analógicas - sobretudo aquelas em que ocorrem nomes próprios no domínio-fonte admitem paráfrases na forma de símile, i.e., admitem o acréscimo da partícula comparativa 
"como", sem perda de conteúdo cognitivo. Isso se dá por conta da grande impertinência ontológica da igualdade que estabelecem (no caso das metáforas afirmativas). A transformação em símile se mostra um meio de mitigar a asserção, deixando claro que não se trata de uma relação de igualdade (de referências) e sim de semelhança.

Parece ser uma peculiaridade do modelo analógico que os nomes próprios que ocorrem na posição de domínio-fonte respeitem sua relação de referência conforme estabelecida pelos usos canônicos (ou literais). Ou seja, no caso de nomes próprios singulares, eles se mantêm designando objetos singulares e não se pode estabelecer nenhuma outra relação de referência que não essa.

Saindo um pouco do escopo da ocorrência de nomes próprios, penso ser possível enquadrar no modelo analógico certas metáforas conceituais apresentadas por Lakoff e Johnson em Metaphors We Live By - mesmo que à revelia dos autores. Metáforas como "Tempo é dinheiro" (LAKOFF; JOHNSON, 2003, p.7) e "Ideias são pessoas" (LAKOFF; JOHNSON, 2003, p.47) são bons exemplo de analogias. "Ideias são pessoas", por exemplo, pode se resolver, em muitos contextos, na seguinte construção proporcional: ideias : pensamento :: pessoas : natureza. Mas não é somente na escolha de exemplos que Lakoff se aproxima do modelo analógico. Em seus trabalhos produzidos a partir da década de 90, o neurolinguista vem sugerindo que correspondências particulares entre certos tipos de fonte e certos tipos de alvo passem a existir em nossa memória semântica de longo prazo devido a experiências sensório-motoras às quais estamos expostos por decorrência de nossa compleição neurobiológica (WEE, 2006, p.360). A operação metafórica que ele chamava à época de Metaphors We Live By de "superposição de domínios" e, após seu engajamento na Teoria Neural da Linguagem, de "mapeamento", tem como base certos conceitos diretamente emergentes de nossa experiência sensório-motora, atuando os mesmos, privilegiadamente, como domínios-fonte - i.e., como conceitos a partir dos quais experiências menos claras são sistematizadas e compreendidas. Essa sistematização seria, de acordo com Lakoff, marcada pela coativação de dimensões comuns a ambos os domínios (em termos neurolinguísticos, "nós neuronais"), numa relação de consistência em que as relações estruturais de cada domínio 
seriam preservadas na ocasião do mapeamento ${ }^{5}$. Ao princípio que zela por essa consistência estrutural Lakoff confere o nome de "Princípio de Invariância" (LAKOFF, 1993, p.215). Segundo Wee, "o Princípio de Invariância de Lakoff sustenta que mapeamentos metafóricos preservam a topologia cognitiva (isto é, a estrutura imago-esquemática) do domínio-fonte de um modo consistente com a estrutura inerente ao domínio-alvo." (WEE, 2006, p.360). Veremos a seguir, dentre outras coisas, que metáforas categóricas não respeitam esse princípio estabelecido por Lakoff.

\section{Ocorrência de nomes próprios em metáforas categóricas}

A primeira coisa a dizer, no que tange à ocorrência de nomes próprios na posição de domínios-fonte no modelo categórico (ou de inclusão em classes), é que a referência dos mesmos se altera, sendo a possibilidade do emprego do artigo indefinido apenas uma das evidências dessa alteração. Nesse tipo de metáfora, os nomes próprios, ainda que ocorram no singular, passam a responder por toda uma classe de objetos. É o que ocorre com "Viena" em "Trieste não é uma Viena". Mas como pode um nome próprio funcionar como nome de classe? Uma teoria tradicional do conceito não pode dar conta de tais casos de modo satisfatório, mas a Teoria do Conceito Prototípico pode. E é justamente a ela que recorrem Sam Glucksberg e Boaz Keysar ao se depararem com tal dificuldade.

Em seu artigo "Understanding Metaphorical Comparisons: Beyond Similarity", Glucksberg e Keysar mostram que certas metáforas simplesmente não admitem ser tratadas como símiles implícitos e argumentam que tais metáforas "são exatamente o que elas aparentam ser: asserções de inclusão em classe" (GLUCKSBERG; KEYSAR, 1990, p.3). E desenvolvem essa tese sustentando que, em tais asserções, o veículo metafórico se refere, a um só tempo, a uma categoria e a um exemplar prototípico dessa categoria (GLUCKSBERG; KEYSAR, 1990, p.11). É

\footnotetext{
${ }^{5}$ Assim, por exemplo, o nosso conceito de conversa se ordenaria a partir de uma Gestalt central, com algumas dimensões como participantes, partes, estágios, sequência linear, causação, propósito (LAKOFF; JOHNSON, 2003, p.78) e talvez se possa dizer que, nesse caso, a Gestalt seria a dos participantes em círculo, com cada um tomando a palavra por vez e de uma prática regida por um espírito de cooperação. Segundo os autores, essa Gestalt diretamente emergente poderia servir de base para a estruturação da metáfora "Discussão é guerra", na qual o conceito inicial de conversa dá lugar ao conceito de discussão, que compartilha com o primeiro muitas dimensões semelhantes, mas que só podem ser compreendidas mediante a um recurso à Gestalt de guerra. Isso significa, em termos linguísticos, usar o vocabulário relacionado à guerra ("inimigo", "vitória", "retaliação") para compreender o referente da palavra "discussão", i.e., a experiência de discussão.
} 
nestas bases que eles demarcam o território daquele modelo de metáfora que chamei acima de "metáforas categóricas". Mas, para que se compreenda devidamente sua argumentação, farei antes algumas considerações sobre a Teoria do Conceito Prototípico desenvolvida por uma de suas fundadoras, a antropóloga e psicóloga cognitiva Eleanor Rosch.

A Teoria do Conceito Prototípico diz, em linhas gerais, o seguinte: o ponto de partida de formação de um conceito simples é sua emergência direta da experiência, tendo como eixo ordenador um protótipo. Rosch, com base em dados obtidos em pesquisas de campo (como aquela sobre categorias de cor, feita com o povo Ndani) procurou provar que a mente humana forma seus conceitos com muito mais frequência a partir de associações por semelhanças de família, num modelo wittgensteiniano, do que por ordenação de traços distintivos de gêneros e espécies, num modelo kantiano-aristotélico. Alguns importantes resultados dessa pesquisa foram publicados no artigo "Natural Categories". Neste artigo e em alguns outros publicados à mesma época, Rosch desenvolve uma teoria dos conceitos fundada na ideia de que alguns membros de uma categoria são melhores exemplos dessa categoria do que outros. Daí advém a noção de protótipo. Um protótipo seria a função de modelo que tendemos a conferir a um indivíduo-padrão ou evento-padrão com relação a outros indivíduos, ações ou eventos. Esses indivíduos, ações ou eventos compartilhariam, em maior ou menor grau, propriedades com o modelo. Desse modo, teríamos mais facilidade em identificá-los como pertencentes a um certo grupo (caindo sob um certo conceito) na medida em que esses objetos apresentem mais características em comum com o objeto-padrão, e teríamos menos facilidade para fazer tal instanciação em caso contrário. Seria possível, assim, o estabelecimento de uma estrutura graduada determinando se e em que medida um indivíduo cai sob um conceito.

Rosch fornece, à guisa de exemplo, o protótipo de pássaro. O indivíduo-padrão para pássaro que vigora em nossa comunidade linguística é o de um passarinho de tamanho não maior do que a palma da mão, capaz de voar com desenvoltura e capaz de cantar - para citar apenas algumas características deste protótipo. Sabiás são, em geral, maiores que a palma da mão, mas voam perfeitamente, e, na mesma medida, cantam. Indivíduos dessa espécie seriam mais facilmente identificados (por integrantes de nossa comunidade linguística) como pássaros do que indivíduos da espécie dos avestruzes. Se Rosch está certa, não precisamos ir muito 
longe para encontrar exemplos de conceitos prototipicamente formados. Os entusiastas da tese defendem que tais conceitos (e não aqueles que seguem o modelo tradicional e têm sua extensão determinada por definições) são hegemônicos na linguagem corrente. Defendem, por exemplo, que, ao invés de aprendermos a usar a palavra "ferramenta" com a função de predicado, a partir de uma definição cabal de ferramenta, orientamo-nos, em nossa aprendizagem, por um protótipo - nesse caso (e para nosso meio cultural estritamente), o martelo.

Após essas breves considerações, voltemos ao texto de Glucksberg e Keysar. Quero ressaltar o importante apontamento feito por estes autores quanto ao fato de que o referente de um determinado nome pode designar um indivíduo (ou grupo específico) pertencente a diversas categorias, o que inclui categorias para as quais não há na linguagem corrente nenhum nome convencionado. Metáforas, de acordo com eles, podem atuar preenchendo essa lacuna semântica por meio de uma modificação na extensão do conceito associado a esse nome ${ }^{6}$ de indivíduo (ou grupo específico). Os autores fornecem, ao início do texto, exemplos de metáforas categóricas que não envolvem nomes próprios tais como "Meu avô é um bebê" e "Meu trabalho é uma prisão". Assim como prisões pertencem a categorias bem determinadas linguisticamente, como edificações e punições, assim também elas podem pertencer a categorias anônimas, como aquela que reúne em si integrantes com as seguintes notas características: "Eles [esses integrantes da categoria] são desagradáveis, confinantes e sufocantes; pessoas estão lá contra sua vontade; é difícil sair deles; eles não são recompensadores; e assim por diante" (GLUCKSBERG; KEYSAR, 1990, p.7). Na sequência, os autores mostram que, no caso da metáfora examinada, o nome "prisão" funciona como protótipo dessa classe sem nome, e sugerem que é uma característica típica da metáfora a exposição, na proposição, desse protótipo7. Dessa forma, o nome de um indivíduo ou espécie

\footnotetext{
6 A bem da verdade, foi o psicólogo social Roger Brown (professor da já mencionada E. Rosch) o primeiro a trabalhar essa ideia, afirmando que: "metaphor differs from other superordinate-subordinate relations in that the superordinate is not given a name of its own. Instead, the name of one subordinate (i.e., the vehicle) is extended to the other (...)" (BROWN, 1958, p. 140).

7 Como meio de superar uma possível estranheza e rejeição, por parte do leitor, da teoria prototípica do conceito e da tese de que metáforas atuam alterando as extensões canonicamente estabelecidas dos termos, os autores mencionam a Linguagem Americana de Sinais. Esse sistema linguístico é apresentado como um paradigma de
} 
passa a responder por todo o gênero.

Essa exposição sentencial do protótipo é a chave para compreendermos como nomes próprios podem servir à categorização via metáfora. Sem dúvida, há diferenças notórias entre o exemplo de metáfora categórica fornecido inicialmente por Glucksberg e Keysar, "Meu trabalho é uma prisão", e aquele de que tratamos acima, a saber, "Trieste é uma Viena". Se "prisão" é um nome que os gramáticos tomariam tacitamente como exemplo típico de um nome comum, operando largamente como termo geral em nossa linguagem natural, o mesmo não se dá como nomes próprios como "Viena". Mas me parece que agora fica claro que o que ocorre em ambos os casos é a exposição de um protótipo - o exemplar que funciona ou deve funcionar como eixo de constituição da classe - na posição de domínio-fonte.

Nestas bases e avançando um pouco para além do escopo da ocorrência de nomes próprios em metáforas, sustento que metáforas conceituais como "Discussão é guerra" (LAKOFF; JOHNSON, 2003, p.4) e "Amor é loucura" (LAKOFF; JOHNSON, 2003, p.49) - em detrimento de serem apresentadas por Lakoff e Johnson indistintamente junto a metáforas analógicas - operam, em geral, como metáforas categóricas. Pode parecer estranho que esses autores tenham negligenciado um tipo de metáfora que tem como cerne um conceito prototípico, uma vez que foram eles os primeiros a chamar a atenção da comunidade filosófica para a relevância da Teoria do Conceito Prototípico. O ponto é que, apesar de admitirem que os protótipos desempenhem papel central na formação de conceitos na linguagem natural, eles não trabalham com a ideia de que haja protótipos em potencial em nossa linguagem e de que caiba a certos tipos de metáfora trazê-los à tona ${ }^{8}$. O fato de não trabalharem com essa

sistema em que fica bem explícito o uso do nome "de um membro de uma categoria prototípica como o nome para a categoria ela mesma" (GLUCKSBERG; KEYSAR, 1990, p.8).

8 Em sua Ciência Nova, Vico subsume metáforas a fábulas e fábulas ao modo alegórico de expressão. Assim, falar alegoricamente não envolveria o estabelecimento de analogias, significados analógicos, e sim o estabelecimento de "significados unívocos" os quais abrigariam "diversos particulares sob um gênero poético" (ZIR, 2009, p.111). É uma leitura plausível aquela que vê no pensador italiano um insuspeito precursor da posição defendida por Glucksberg e Keysar, a saber, a de que, em certas ocasiões, quando falamos metaforicamente de $A$ em termos de $B$, não dizemos que $A$ é semelhante a $B$, mas vinculamos diretamente $A$ a B. De acordo com Alexandre Zir, Vico desenvolve a tese de que não só o aprendizado e a renovação da linguagem, mas sua própria constituição é fundada em metáforas categóricas como a seguinte: "quando, 'dois mil anos após o dilúvio universal', os homens da terra foram atraídos para contemplar o céu 'pela força dos raios surgidos da atmosfera seca', deram a ele a sua própria natureza de 'gigantes robustos', que 'berrando e protestando expressavam suas violentíssimas paixões', 'chamando-o Zeus'. Não era que o céu, objeto físico e inanimado, fosse parecido com um ser animado e violento - 
concepção de linguagem, é, penso eu, causa das maiores dificuldades que podem aparecer quando procuramos aplicar a concepção de metáfora desenvolvida por Lakoff e Johnson aos estudos de literatura. Os autores comprometem as metáforas novas, por um lado, somente com derivações feitas a partir da detecção de traços salientes, bem conhecidos e distintivos dos objetos considerados e, por outro, com uma concepção de linguagem que não dá muita margem às transgressões categoriais significativas. Essa rigidez de pressupostos torna árida a tarefa de estudar, a partir da Teoria da Metáfora Conceitual, os "padrões metafóricos distintivos e idiossincráticos na obra de um autor" (SEMINO; STEEN, 2010, p. 244).

\section{Contrastes entre os dois modelos}

Colocando em contraste os dois modelos apresentados, de modo a obtermos esclarecimentos sobre o papel dos nomes próprios como signos de domínios-fonte de metáforas, podemos concluir que, diferentemente do modelo analógico, o modelo categórico não se funda no estabelecimento de correspondências entre a estrutura interna do domínio-fonte e a estrutura interna do domínio-alvo. Ao invés disso, o que ocorre é simplesmente a delineação, a partir de uma asserção (e não de uma identificação), de uma categoria não canônica. As posições de Glucksberg, Keysar, McGlone e Lionel Wee - no artigo "Proper names and the theory of metaphor" - convergem para a afirmação de que tal categoria seria: a) construída, b) ad hoc e c) de ordem superior (superordinate). Tenho restrições quanto a essa última classificação e, ao fim deste trabalho, procurarei expô-las. Não posso me furtar a assumir, contudo, que certos apontamentos feitos por Wee são muito esclarecedores. Dentre eles aquele em que o autor afirma que:

Estabelecer propriedades relacionais entre fonte e alvo - a raison d'être do modelo correspondentista - não é um comprometimento do modelo de inclusão em classe (...) Glucksberg e McGlone não recorrem a correspondências (e talvez não possam fazê-lo) porque eles tratam a fonte como um exemplo prototípico de uma categoria de ordem superior. E a

\footnotetext{
mais que isso, ele pertencia à classe dos 'gigantes robustos', representada na sentença pelo protótipo 'Zeus'". (ZIR, 2009, p.113). Mas faço essa consideração somente com o intuito de fornecer outro bom exemplo de metáfora categórica e para expressar minha perplexidade diante da insuspeita contemporaneidade do pensador italiano no que diz respeito a sua concepção de metáfora. No mais, não discutirei aqui a tese (comum a Vico, Rousseau e Nietzsche) de que os processos de formação das categorias (literais e figuradas) são, eles próprios, metafóricos.
} 
relação entre um protótipo (p.ex.: um robin) e sua categoria (p.ex.: pássaro) não pode ser reduzida a um conjunto de correspondências. Por exemplo, é estranho sugerir que um robin CORRESPONDE a um pássaro. A relação, ao invés disso, é uma relação de INSTANCIAÇÃO. (WEE, 2006, p.361)

Deve-se notar que Wee sublinha a diferença entre metáforas analógicas (correspondentistas) e categóricas (de inclusão em classe) apresentando razões de ser ou finalidades diferentes para cada uma. Enquanto a finalidade do modelo analógico seria estabelecer propriedades relacionais entre fonte e alvo, a finalidade do modelo categórico seria criar ou evidenciar uma categoria para a qual nossa linguagem não oferece um nome adequado. No segundo caso, essa nova categoria seria nomeada a partir do estabelecimento de um nome prototípico e da instanciação inusitada de um objeto dentro de uma categoria a ser ordenada a partir do referente desse nome prototípico - ou de um sistema de propriedades cultural ou contextualmente associado a esse referente. Wee argumenta que a relação entre um protótipo (referente do nome prototípico) e uma categoria (seja ela uma categoria canônica ou recém-estabelecida pela metáfora) não pode ser reduzida a uma relação de correspondência.

Não há por que discordar de Aristóteles quanto ao evidente valor cognitivo das analogias (ARISTÓTELES, 2000, 1411 b 25-30). Elas, decerto, são um excelente recurso para a detecção de semelhanças valiosas e inesperadas (ARISTÓTELES, 2000, 1412 a 15-20). Contudo, a relação analógica é essencialmente uma relação fundada em semelhanças de ocasião, sem grande comprometimento ontológico ${ }^{9}$. O modo como as analogias preenchem lacunas semânticas (quando elas o fazem) difere claramente do modo como metáforas categóricas preenchem lacunas semânticas. No caso da transferência analógica de nomes, há uma equivalência no nível de abstração ou generalidade entre o lugar de origem termo transferido e o lugar que ele passa a ocupar. Em "O sol semeia seu fogo divino" (ARISTÓTELES, 2000, 1457 b 28-30), temos sol : $x$ :: semente : semear, de modo que $x$ deve estar no lugar de uma ação sem nome e que a transferência de "semear" para a posição $x$ deve respeitar a identidade de relação estabelecida pela proporção. Já no caso das metáforas categóricas, impera um desnível de abstração ou generalidade entre os termos que compõem a própria proposição, sendo esse

9 Emprego o termo "ontologia" ao longo deste artigo, seguindo sugestão de teóricos da metáfora como Black, Cazeaux e Ricoeur, na seguinte acepção: diz respeito às convicções acerca do que é (factual), enquanto expressas por meio de estabelecimentos categoriais acerca da estrutura básica de tudo o que é (factual). 
desnível o que permite a instanciação. A compreensão da instanciação envolve que se desloque semanticamente os termos expostos de suas categorias habituais e que se busque uma categoria nova que possa abrigar ambos, tomando-se como fio condutor o funcionamento do termo que ocorre no domínio-fonte como termo prototípico dessa nova categoria.

Isso posto, penso ter deixado explícito que carece de uma informação valiosa no que diz respeito ao estudo do papel cognitivo das metáforas uma teoria que não trabalhe com a ideia de que uma metáfora em que ocorre um nome próprio possa estabelecer (revelar) uma categoria para a qual falta um nome adequado na linguagem, i.e., de que o domínio-fonte de uma metáfora possa ser ele mesmo "uma instanciação prototípica de uma categoria mais ampla, recém-criada e de ordem superior, a qual é então vista como englobando tanto o domínio-fonte quanto o domínio-alvo" (WEE, 2006, p.36o). Mas esse é justamente o caso da Teoria da Metáfora Conceitual, estabelecida por Lakoff e Johnson.

A partir dos exemplos apresentados na próxima seção, mais do que boas ilustrações do contraste aqui estabelecido entre os modelos analógico e categórico de metáfora espero estabelecer critérios mais encorpados para sustentá-la.

II.

Dedicarei essa seção a explorar os modos como as duas espécies de metáfora estabelecidas acima vêm ocorrendo em grandes obras da literatura. Como raras são as abordagens filosóficas da metáfora em publicações nacionais, o que implica em não serem muitas as ocasiões em que exemplos literários endógenos são celebrados nessa área, faço questão de iniciar essa segunda seção com algumas boas amostras de grande estilo daquele que é um dos maiores escritores de língua portuguesa.

Machado de Assis nos fornece, ao longo de sua obra, inúmeros exemplos de metáforas analógicas e de metáforas categóricas. Para não nos perdermos na imensidão da obra do bruxo do Cosme Velho, atenhamo-nos a seu Dom Casmurro. No capítulo 80 da referida obra, encontramos o narrador (Bentinho / Dom Casmurro) recapitulando aquela fase de sua adolescência em que foi mandado por sua mãe (por força de uma promessa feita a Deus) para 
um seminário, com a incumbência de seguir a carreira eclesiástica. É importante ressaltar que a mãe não o fazia por gosto e sim pelo dever de cumprir a promessa. Nesse ínterim, Capitu, a namoradinha do narrador à época - e posteriormente sua oblíqua e dissimulada mulher -, aproxima-se da futura sogra. É então que, segundo nos conta o narrador, "a esperança de que nosso amor, tornando-me absolutamente incompatível com o seminário, me levasse a não ficar lá nem por Deus nem pelo diabo, esta esperança secreta entrou a invadir o coração de minha mãe". (MACHADO DE ASSIS, 1997, p.152). Visando esclarecer o lugar de cada personagem nesse momento da trama, Machado, pela boca de Bentinho, nos põe diante do seguinte esquema metafórico, estabelecido com base em uma célebre passagem do Antigo Testamento:

Como Abraão, minha mãe levou o filho ao monte da Visão, e mais a lenha para o holocausto, o fogo e o cutelo. E atou Isaac em cima do feixe de lenha, pegou do cutelo e levantou-o ao alto. No momento de fazê-lo cair, ouve a voz do anjo que lhe ordena da parte do Senhor: "Não faças mal algum a teu filho; conheci que temes a Deus". Tal seria a esperança secreta de minha mãe.

Capitu era naturalmente o anjo da Escritura. (MACHADO DE ASSIS, 1997, p.152)

Nessa passagem, temos três metáforas em que constam nomes próprios: "Minha mãe era (como) Abraão"10, "Eu era Isaac" e "Capitu era o anjo da Escritura". Em todos os casos, o modelo analógico de metáfora é seguido à risca. É interessante notar como Machado extrai o que há de melhor nesse tipo de metáfora ao apresentar não uma analogia solitária, mas um sistema delas.

No capítulo 69 da mesma obra, o narrador nos relata sua ida à missa buscando uma reconciliação interesseira com Deus. Após a convalescença de sua mãe, interessava a Bentinho fazer com que Deus renunciasse ao pagamento de sua promessa de rezar dois mil padre-nossos se a mesma se recuperasse da doença que a acometia. Nutria esperanças de que Deus acederia a seu pedido pois entendia que "Jeová, posto que divino, ou por isso mesmo, é um Rothschild muito mais humano e não faz moratórias, perdoa as dívidas integralmente, uma vez que o

10 Assim como Aristóteles o faz na Retórica, pode-se considerar aqui o símile um tipo mais fraco de metáfora (ARISTÓTELES, 2000, 1410 b 20-25). 
devedor queira deveras emendar a vida e cortar nas despesas" (MACHADO DE ASSIS, 1997, p.137 $)^{11}$. Notemos que, neste caso, temos um ótimo exemplar das metáforas categóricas de que falam Glucksberg e Keysar. A presença do artigo indefinido o acusa de imediato.

É verdade que o autor insere na metáfora certas ressalvas para a instanciação de Jeová na classe cujo protótipo é Rothschild. Mas um exame de tais ressalvas revela que elas não são um empecilho e sim como um reforço para a tese que aqui venho erigindo. $O$ fato de Machado fazer ressalvas como relação à sua categorização de Jeová como um banqueiro do tipo Rothschild abre espaço para uma consideração das categorizações graduadas e condicionadas e, inclusive, para considerarmos as negações de metáforas ou metáforas negativas. Mas esse ponto será melhor desenvolvido abaixo.

Por ora, sejamos mais sistemáticos e ponhamos lado a lado duas proposições metafóricas apresentadas acima, uma seguindo o modelo analógico e a outra seguindo o modelo categórico:

(3) "Bentinho é Isaac"

(4) "Jeová é um Rothschild"

Como já vimos, (3) é um caso do modelo analógico, tem a forma "a é b", onde a e b são postos em relação a partir de uma seleção dos aspectos de b que permitem uma leitura contextualmente coerente de a. Os dois indivíduos continuam sendo a referência dos nomes. No que tange ao jogo de ênfases que é efetuado pela seleção de aspectos relevantes, a metáfora só torna mais explícito o que, assim entendo, ocorre em qualquer tipo de descrição de objetos empíricos, incluindo-se aí as chamadas descrições literais ${ }^{12}$.

11 "Rothschild" como signo de designação de um indivíduo singular parece dizer respeito a Mayer Amschel Rothschild, banqueiro judeu nascido em Frankfurt que formou uma linhagem de banqueiros possivelmente detentora da maior fortuna privada do mundo ao longo do século XIX.

12 Quando opomos uma sentença como "O gato está sobre o capacho" a uma sentença metafórica como "Uma onda de religiosidade invadiu a Europa", não estamos absolutamente opondo uma descrição objetiva dos fatos a uma descrição subjetiva dos fatos, não estamos opondo denotação a conotação, independência contextual a dependência contextual, ou qualquer coisa do gênero. Estamos opondo duas formas distintas de edição. Cada uma delas envolve uma forma distinta de seleção de aspectos relevantes. E o termo "relevância" aqui é escolhido a dedo: toda seleção de aspectos se funda em avaliações do que é adequado ou satisfatório no jogo de linguagem, ou seja, funda-se em habilidades contextuais como a de controle de quantidade de informações. Como nota Searle, 
Já em (4), o nome "Rothschild" é ele mesmo o nome para a categoria de objetos em que cai Jeová. O uso do artigo indefinido é um traço marcante dessa referência a uma categoria. Assim, fica difícil compreender (4) em termos de uma correspondência entre a e b. Como vimos, uma correspondência entre $a$ e $b$ exige que ambos os termos estejam no mesmo nível de abstração. Por outro lado, se $b$ instancia $a$, então $a$ está em um nível de abstração (generalidade) mais específico do que $b$. Desse modo, uma relação analógica pode explicar o que se passa em (3), mas não pode explicar o que se passa em (4).

Perceba-se que o acréscimo da partícula comparativa "como" (tornando o enunciado um símile) pode ser feito, sem alteração de sentido, em (3) e não pode ser feito em (4). Paráfrases como "Bentinho é como Isaac" e "Bentinho é como Isaac com relação a terem os dois as propriedades $X, Y$ e $Z$ " somente deixam evidente que, no contexto, o comprometimento do autor com uma veemência ontológica de seu enunciado não é extremada. O "como" e as especificações de propriedades compartilhadas deixam explícito que se deve mitigar a asserção de identidade. O narrador não requer de nós que compreendamos a inesperada revelação de que ele mesmo Bentinho, esteve no Monte Moriá e quase foi morto por um dos patriarcas do povo judeu. Ao evocar a célebre passagem do Antigo Testamento, ele propõe um modelo, um esquema, que se liga aos fatos narrados anteriormente por analogia. Trata-se de todo um sistema coerente de analogias em que cada personagem de uma narrativa encontra como contraparente proporcional uma personagem da outra narrativa. Assim, para compreender melhor o papel de Bentinho, de sua mãe e de Capitu na narrativa (domínio) da ida para o seminário, devemos projetar sobre os mesmos nossa compreensão das relações entre Isaac, Abraão e o anjo - nessa ordem - na narrativa (domínio) dos eventos ocorridos no cimo do Monte Moriá. No caso da sentença metafórica em questão, a estrutura analógica pode ser explicitada por duas vias diferentes: 1) Bentinho : Capitu :: Isaac : anjo e 2) Bentinho : sua mãe :: Isaac : Abraão. Mas essas vias não se excluem, elas cooperam na contribuição para a compreensão da situação descrita. Na Poética de Aristóteles, fica explícito que uma metáfora que procede por analogia se apoia em uma identidade de relação (ARISTÓTELES, 2005, 1457 b

no caso de "O gato está sobre o capacho", nada é dito na primeira sentença, por exemplo, sobre a posição da cabeça do gato ou sobre o fato de estarmos sob efeito do campo gravitacional da Terra - ainda que o uso da palavra "sobre" só tenha sentido a partir dessa "suposição de base". (SEARLE, 2005, p.122) 
15-20). Nesse caso, como temos todo um esquema analógico, temos duas identidades relacionais. A primeira consiste em que ambos, Bentinho e Isaac, seriam salvos por intervenção de instância superior inefável (seja o amor, seja o anjo do senhor) e a segunda em que ambos, Bentinho e Isaac, estariam sujeitos aos caprichos da fé de seus pais.

Mas nada disso se aplica à metáfora (4). Neste caso, a inserção da partícula comparativa "como", e a consequente transformação do enunciado em um símile, simplesmente arruinaria a forma categórica da proposição. Tal paráfrase ignoraria temerariamente a função do artigo indefinido na composição machadiana. E é justamente esse artigo o indício mais evidente de que o verbo "ser" não aparece com o sentido de identidade e sim o de atribuição. Com base nos apontamentos de Wee, podemos dizer que os termos "Jeová" e "Rothschild" não estão funcionando no mesmo nível de abstração. Enquanto o primeiro nome tem como referência somente um objeto singular, o último opera como protótipo para a ordenação de uma categoria de objetos. Talvez se possa arriscar dizer que a categoria em jogo aí é a dos poderosos negociantes judeus.

Não poderíamos falar em uma categoria muito restrita como a categoria dos poderosos banqueiros alemães do século XIX, pois, neste caso, a categorização feita pela asserção metafórica seria patentemente falsa, um equívoco onto-teológico crasso que não se esperaria de Bentinho. Desse modo, a proposição nos convida a considerar Jeová por uma face inusitada, mas não impertinente. Jeová se revela um tipo de negociante e isso, na concepção desconfiada de Bentinho, não deve ser tomado como um modo de dizer, não deve ser mitigado. Se há algum abrandamento a ser feito, o próprio narrador (Bentinho) o faz, mas não renegando o caráter assertórico de seu proferimento e sim inserindo nuances no mesmo. Ele quer revelar a face negociante de Jeová sem, com isso, afrontar a natureza e, sobretudo, a autoridade divina desse último. Desse modo, a solução é se valer do estabelecimento de uma estrutura graduada que permita um cálculo da aproximação entre domínio-alvo e domínio-fonte. O narrador afirma que, por ser divino, Jeová, ainda que lhe caiba a alcunha de poderoso negociante judeu, não compartilha com o referente do nome prototípico todas as propriedades que o fazem prototípico. Jeová, diferentemente de Rothschild, "não faz moratórias, perdoa as dívidas integralmente, uma vez que o devedor queira deveras emendar a vida e cortar nas despesas" 
(MACHADO DE ASSIS, 1997, p.137). Perceba-se que a aproximação com base em gradações é um recurso que só se faz viável quando estamos lidando com a inserção de um indivíduo em uma classe, i.e., metáforas categóricas. O mesmo não se passa com metáforas como (3), i.e., metáforas analógicas. Isso porque o que torna possível a transferência metafórica de nomes em uma analogia é uma identidade de relação, a qual, sendo identidade, não admite gradação (não se pode falar em "mais idêntico" ou "menos idêntico")13.

Detenhamo-nos um pouco mais nesse aspecto da gradação. Em um artigo denominado "Ad hoc categories", Lawrence Barsalou segue a trilha aberta pela descoberta da estrutura graduada dos conceitos (levada a cabo por Rosch, dentre outros) e demonstra que conceitos ad hoc (como "coisas para se vender em uma venda de garagem") apresentam gradações de similaridade que operam do mesmo modo que operam as gradações de similaridade em categorias comuns (como "frutas" e "mobília"). Ele apresenta provas empíricas de que conceitos ad hoc são marcados por: 1) tipicalidade (typicality) - "o fato de que algumas instâncias são melhores exemplos de uma categoria do que outras" -, 2) ocorrência de casos de borda - "as pessoas não sabem ao certo se 'rádio' pertence à categoria 'mobília'" e 3) não-membros de uma categoria variarem acerca do quanto eles são similares ao conceito dessa categoria - " 'morcego' leva mais tempo para ser rejeitado como membro da categoria dos 'pássaros' do que 'cadeira'" (BARSALOU, 1983, p.211). Segundo o autor, esses seriam três aspectos fundamentais das categorias da linguagem natural (sejam elas comuns ou ad hoc). Se aceitamos as evidências fornecidas por Barsalou e se admitimos, entrando em acordo com Glucksberg e Keysar, que "categorias metafóricas, como um caso especial de categorias funcionais ad hoc, devem ter também elas estruturas graduadas" (GLUCKSBERG; KEYSAR, 1990, p.14), então, será forçoso assumir que metáforas categóricas em que ocorrem nomes próprios também devem ter estruturas graduadas. $E$, como foi dito acima, o mesmo não vale para metáforas analógicas.

\footnotetext{
13 Nossa linguagem nos perimte, decerto, ver sentido em construções sentenciais como "Bentinho é meio Isaac" ou "Bentinho é muito Isaac", mas, nesses casos, o que parece o recurso a uma estrutra metafórica graduada não senão o recurso a uma gradação habitual (literal) de identificação (e não de categorização): a expressão "parecido com" (ou outra que a valha, como "semelhante a") está implícita nas sentenças e sua explicitação - "Bentinho é muito parecido com Isaac" - mostra que o que parece ser uma metáfora não passa de uma composição habitual.
} 
Eis mais um critério de distinção entre metáforas analógicas e categóricas. E esse critério parece mais confiável do que aquele outro que tínhamos adotado de início, o qual se restringia à constatação da presença de um artigo indefinido. Ainda que o artigo ocorra, de modo exemplar, na metáfora de Machado, muitos são os casos em que o critério pode falhar.

Examinemos, a propósito, um caso em que o critério do artigo indefinido falha. Na obra de um dos maiores estilistas da língua alemã podemos encontrar um interessante caso de metáfora categórica em que o artigo definido não se faz presente. No primeiro volume de seu Fausto, Goethe nos faz espectadores de uma visita de Mefistófeles e o protagonista à cozinha de uma feiticeira. A poção mágica preparada pela feiticeira é descrita como tendo o seguinte efeito:

Quando a bebida no corpo tiveres

Helenas verás em todas as mulheres ${ }^{14}$

Aplicando o critério que acabamos de estabelecer acerca da estrutura graduada à metáfora de Goethe, podemos perceber que o emprego de termos de gradação para estabelecer relações de tipicalidade entre cada mulher e o protótipo da categoria das Helenas, a saber, Helena, é perfeitamente cabível. O desenvolvimento da narrativa nos dá margem para afirmar que, no que diz respeito ao julgamento de Fausto, Margarida é mais Helena que Marta ou que Marta é menos Helena que Margarida, por exemplo.

Mas há mais uma característica dessa metáfora que precisamos considerar. Se, por um lado, é nela notória a ausência do artigo indefinido, por outro lado, temos a ocorrência do nome próprio no plural. Sobre tal tipo de ocorrência, Wee faz o seguinte apontamento:

Relembre que, sob o modelo de inclusão em classes, a fonte tem como referência tanto a categoria de ordem superior quanto um membro daquela categoria. Nesse caso, a pluralização faz sentido, dado que o nome, ao mesmo tempo que designa um indivíduo particular, também designa a categoria de ordem superior, a qual esperamos conter múltiplos membros. (WEE, 2006, p.362)

14 "Du siehst mit diesem Trank im Leibe / Bald Helenen in jedem Weibe" (GOETHE, 1998, p.100). 
Essa ocorrência de nomes próprios no plural na posição de domínios-fonte é uma via pela qual se põe em xeque o Princípio de Invariância proposto por Lakoff. Vimos acima que o Princípio de Invariância estabelece que mapeamentos metafóricos devem preservar a topologia cognitiva do domínio-fonte de um modo consistente com a estrutura inerente ao domínio-alvo. Ora, o nome "Helena", na metáfora de Goethe, se refere a um só tempo a um indivíduo particular (ainda que ficcional) e a uma categoria ad hoc - algo como "mulheres cuja beleza é potencializada por encanto". Deste modo, não se pode falar de uma topologia única no domínio-fonte. A metáfora de Goethe se mostra avessa a uma abordagem a partir do modelo analógico não somente por possuir uma estrutura graduada, mas também por ferir o Princípio de Invariância.

\section{III.}

Ora, vimos tematizando a categorização via metáfora, mas ainda não exploramos devidamente o que se intenciona e o que se pode realizar com esse recurso. Para estabelecermos essa discussão, devemos dar ouvidos, antes de mais nada, à seguinte advertência: uma teoria da metáfora não se deve limitar a tomar como pressuposto uma linguagem-espantalho, morta, não suscetível a conflitos semânticos. Quando isso ocorre, perde-se de vista o fato de que a categorização via metáfora não pode se dar senão através da transgressão significativa dos usos canônicos da linguagem.

Se há metáforas literárias como "Bentinho é Isaac", as quais não têm qualquer pretensão de desafio aos quadros categoriais canônicos (e se curvam passivamente à conversão em símiles), há também metáforas literárias que parecem se comprometer fortemente com uma recategorização. O que estou querendo dizer é que ainda não chegamos ao fundo de nosso exame se não exploramos o que possa ser a "veemência ontológica" (RICOEUR, 1975, p.313) em jogo nos tipos de metáforas que ora consideramos. Um contraste entre duas metáforas presentes em A Montanha Mágica, de Thomas Mann, permitir-nos-á galgar mais um degrau em nossa análise da ocorrência de nomes próprios em metáforas. 
Em diversas passagens de A montanha Mágica, Mann provoca o leitor no sentido de fazê-lo perder de vista as diferenças individuais entre as personagens Clawdia Chauchat e Pribislav Hippe. Por uma perspectiva em que "lucidez" diz respeito a seguir os estabelecimentos do senso-comum, Hippe é um rapaz saudável, de seus 13 anos, um amor de ginásio pertencente ao passado de Hans Castorp, ao passo que Clawdia é uma mulher doente, adulta e casada, um amor pertencente ao presente de Castorp. Entretanto, por uma perspectiva em que "lucidez" diz respeito à capacidade de conceber e descrever fielmente as experiências vividas, Hippe e Clawdia, com seu exotismo, seus "olhos quirguizes" (MANN, 1980, p.138), mesclam-se em um só ente. Para além da semelhança dos olhos quirguizes, é, sobretudo, a semelhança entre os episódios de empréstimo de lápis (tanto Hippe quanto Clawdia emprestam lápis a Castorp) que opera como ponto de fusão. Eis algumas passagens que contribuem para o fortalecimento dessa última perspectiva:

Estás vendo? Eu já sabia que tinhas um lápis. (MANN, 1980, p.372)

Sei tudo a respeito do homem; conheci a sua carne; devolvi o lápis de Pribislav Hippe à enferma Clawdia. Mas quem conhece o corpo e a vida, conhece a morte. (MANN, 1980, p.550)

(...) desde muito tempo estava familiarizado com a doença e com a morte, e já nos meus tempos de menino cometi o disparate de te pedir emprestado um lápis, tal como se deu aqui naquela noite de Carnaval (MANN, 1980, p.666)

Ainda que a composição "Clawdia é Hippe" não seja explicitada, diversas passagens como essas a delineiam, permitindo ao leitor uma indagação sobre o quanto a doença de Castorp seria responsável por tal confusão e sobre o quanto essas condensações de referente não podem acometer pessoas tidas como saudáveis (pessoas "da planície"). Mann força ao máximo a metáfora do tipo analógico, apresentando ao leitor uma via pela qual analogias podem sugerir modificações em nossas convicções de ordem ontológica. Contudo, quando se busca, com o emprego de uma metáfora que põe dois nomes próprios em relação analógica, ir além da semelhança, chegando-se mesmo a propor a identificação dos referentes dos nomes envolvidos, a transgressão ontológica se mostra excessiva (sob o ponto de vista de nossos hábitos e expectativas categoriais). O autor está ciente das limitações desse expediente e não é 
sem razão que ele insere as falas de Castorp apresentadas acima em contextos de delírio ou embriaguez.

É algo um tanto distinto o que se dá com a relação estabelecida entre os nomes dos personagens Lodovico Settembrini, Leo Naphta e Mynheer Peeperkorn. O humanista Settembrini e o jesuíta Naphta, em seu constante embate, tornam-se, cada um à sua maneira, mentores de Castorp. Mas sua condição de homens notáveis é consideravelmente ofuscada quando o hedonista Peeperkorn faz sua entrada majestosa na trama. Esse último - que, diga-se de passagem, surge como amante de Clawdia e oponente de Castorp - não é nem de longe uma sumidade no campo das ideias, mas sua postura de "individualidade soberana" (MANN, 1980, p.626), sua presença a um só tempo sedutora e tirânica, levam o protagonista a reconhecer nele não um homem comum, mas uma "personalidade" (Persönlichkeit; MANN, 1980, p.631). E é justamente esse modo de tratamento que nos interessa aqui. A culminância desse contraste entre os dois mentores e o holandês majestoso se dá com uma metáfora expressa pelo narrador:

Não é por acaso - convém reconhecer esse fato - que nos rodeamos de inteligências como as dos Srs. Naphta e Settembrini, ao invés de nos cercarmos exclusivamente de esfumados Peeperkorns. Verdade é que isso nos leva a uma comparação que, sob certos pontos de vista, principalmente no que se refere à envergadura, resultaria vantajosa para a personagem posteriormente apresentada. Também Hans Castorp chegava a essa conclusão, quando se achava estendido no seu compartimento de sacada e refletia sobre os dois educadores excessivamente articulados, que lhe disputavam a pobre alma. Verificava então que eles pareciam anões em confronto com Pieter Peeperkorn, a ponto de sentir-se inclinado a qualificá-los de "pequenos tagarelas", da mesma forma como o holandês, na sua régia ebriedade, fizera humoristicamente com ele mesmo. (MANN, 1980, p.640)

Aqui, mais uma vez, deparamo-nos com uma metáfora categórica marcada pelo uso do nome próprio no plural e pela estrutura graduada. Aos olhos de Castorp, Settembrini e Naphta são excelentes exemplares da classe dos homens doutos e distintos ${ }^{15}$, mas não é a inclusão nessa classe que está em jogo nas considerações citadas. A classe que desponta aí e que tem

15 Como fica explícito na seguinte fala de Castorp: "Tu não és um homem qualquer que leva um nome, tu és um representante, Sr. Settembrini, um representante neste lugar e a meu lado." (MANN, 1980, p.367) 
Peeperkorn como protótipo, é precariamente descrita pelo protagonista em conversa com Settembrini: trata-se de uma classe de indivíduos que se destacam não por sua argúcia, não por meras qualidades físicas, mas por um poder de tornar indistinguíveis o "elemento espiritual" e o "elemento corporal", atuando na ordem do "místico". Nas palavras de Castorp, "Para explicar esse fato, dispomos de uma única palavra: personalidade" (MANN, 1980, p.651). Ou seja, o protagonista elege um indivíduo que responde pela classe das personalidades, que é o porta-voz dessa classe. Mas mesmo essa palavra, "personalidade", parece-lhe inadequada para dar conta do que procura dizer, pois, "empregamo-la também num sentido mais racional, para dizer que se tem personalidade jurídica ou moral ou não sei que personalidades mais" (Idem, ibidem). Daí o narrador, na passagem citada, precisar recorrer ao emprego do próprio nome do indivíduo prototípico para se referir a uma classe que carece de nome adequado.

Mann dá mostras de um capricho de ourives ao fazer o narrador deixar explícito que, com o nome "Peeperkorns", não intenciona se referir somente à classe dos Peeperkorns, mas que, concomitantemente, o termo mantém sua referência ao indivíduo que recebe esse nome (mesmo estando no plural) - o que só vem a corroborar a tese de Glucksberg e Keysar de que, em casos como esse, o nome próprio opera com duas referências.

\section{IV.}

Paul Ricoeur, em A Metáfora Viva, defende a tese de que toda metáfora, por maior que seja sua veemência ontológica, não é senão "ficção heurística" (RICOEUR, 1975, p.301). Entendo que as metáforas que vimos analisando, ainda que ocorram em textos ficcionais, mostram-se bons exemplos em contrário. Metáforas categóricas ocorrentes em textos de literatura, como quaisquer metáforas categóricas, não admitem a redução ao símile e nos servem para a descrição apropriada dos fatos - nas palavras de Aristóteles, servem para "pôr a coisa diante dos olhos" (ARISTÓTELES, 2000, 1405 b 15). Não vejo razões satisfatórias para assumir que a categoria estabelecida a partir do nome "Peeperkorn" deva ser considerada uma categoria ficcional. Ocorre em um texto de ficção, mas não é ficcional ou fictícia. Não há qualquer dificuldade em encontrarmos exemplos de metáforas com estrutura idêntica em 
descrições de fatos que reputamos ser reais. Posso, por exemplo, em conversa com leitores de A Montanha Mágica, classificar, de forma perfeitamente inteligível, amigos em comum como "mais Peeperkorns" ou "menos Peeperkorns". Essa classificação pode, inclusive, ser motivo de disputa e correção. Digo: "X é um perfeito Peeperkorn" e alguém me corrige: "Não... ele está mais para um Settembrini".

E, aqui, volto a afirmar que metáforas com alto comprometimento com a recategorização só podem ser devidamente compreendidas se trabalhamos com uma concepção mais agonística de linguagem, i.e., com uma concepção de que os usos canônicos não somente podem não ser suficientes para a determinação das categorias, mas também que o que deve contar como canônico é, frequentemente, razão de disputa. Visando fortalecer essa posição, proponho examinarmos uma metáfora categórica em que ocorrem nomes próprios com alto teor de comprometimento ontológico. Deixei para o final esse ótimo exemplo garimpado por Shinoff e reproduzido por Glucksberg e Keysar acerca da ocorrência de nomes próprios na posição de domínio-fonte de metáforas categóricas.

Israelense: "Se ele é um Demjanjuk, então ele deve ser condenado à morte." Repórter: "Mas ele é Demjanjuk, o nome dele é John Demjanjuk." Israelense: "Eu sei que o nome dele é Demjanjuk, mas não sei se ele é um Demjanjuk." (SHINOFF apud GLUCKSBERG; KEYSAR, 1990, p.8)

O diálogo acima não é ficcional. Trata-se de um excerto de um artigo de jornal sobre os crimes de guerra de John Demjanjuk, carcereiro nazista acusado de submeter às torturas mais hediondas judeus confinados no campo de concentração de Treblinka. À época do julgamento, o nome "Demjanjuk" havia se tornado, em Israel, uma palavra para classificar uma pessoa comum capaz de cometer atos indescritíveis. Perceba-se que, assim como no caso da metáfora de Mann, uma categoria que carece de um nome apropriado em nossa linguagem foi estabelecida a partir do nome de um indivíduo prototípico, Demjanjuk. O fato de não se saber ao certo se o indivíduo John Demjanjuk deveria ser enquadrado nessa categoria de indivíduos dava margem a construções linguísticas curiosas como: "Demjanjuk não é um Demjanjuk". O que salta aos olhos nesse exemplo é que uma categoria metaforicamente constituída pode decidir a sorte de um indivíduo. Se é verdade que John Demjanjuk é um Demjanjuk, ele deve ser condenado à morte. Esse enunciado pode orientar ações, tem a força de uma máxima. 
Se há uma ideia presente em Metaphors We Live By que me faz entrar em franco acordo com seus autores é a ideia de que há certas metáforas cujo uso só nos parece apropriado quando as mesmas "sancionam ações, justificam inferências e nos fazem atingir objetivos" (LAKOFF; JOHNSON, 2003, p. 142). É justamente isso o que Lakoff e Johnson têm em mente quando distinguem essas metáforas das demais com a alcunha de "metáforas através das quais nós vivemos" (metaphors we live by) e quando sustentam que muitas de nossas atividades (discutir, resolver problemas, orçar o tempo etc) são metafóricas por natureza. Os conceitos metafóricos que caracterizam essas atividades estruturam nossa realidade presente. Novas metáforas têm o poder de criar uma nova realidade. Isso pode começar a acontecer quando começamos a compreender nossa experiência nos termos de uma metáfora e torna-se uma realidade mais profunda quando começamos a agir nos termos dessa metáfora. Se uma nova metáfora adentra o sistema conceitual em que nós baseamos nossas ações, ela irá alterar esse sistema conceitual e as percepções e ações que esse sistema origina (LAKOFF; JOHNSON, 2003, p. 145).

A ideia central da passagem é de que aquilo que os autores chamam de "conceitos metafóricos" (ou "metáforas conceituais") têm, a um só tempo, o poder de promover alterações de cunho ontológico e de operar como máximas. De acordo com eles, há situações em que a metáfora não se apresenta meramente como a enunciação de um modo de ver a realidade, ela pode chegar até mesmo a se constituir como "licença para mudanças estratégicas e para ações políticas e econômicas" (LAKOFF; JOHNSON, 2003, p.156). A ideia é desenvolvida a partir de um contundente exemplo de uso da metáfora como ferramenta de sancionamento e interdição de ações. Por ocasião da crise energética enfrentada pelos Estados Unidos da América no final da década de 1970 (a OPEP tinha posto o preço do barril de petróleo nas alturas), o então presidente estadunidense Jimmy Carter declarou que as ações do governo deveriam se pautar por uma moral de guerra. Essa metáfora da guerra contra as adversidades do ramo da energia deu margem a uma série de ramificações, como a ideia de que havia um "inimigo a ser combatido" e que alguns "alvos deveriam ser estabelecidos" (por exemplo, o embargo das importações de produtos iranianos ou a remoção dos controles de preço). 
Vejo também no caso da metáfora "X é um Demjanjuk" uma metáfora pela qual nós vivemos. Na metáfora israelense a orientação da ação também se dá mediante uma descrição metafórica (mas não fictícia) dos fatos. Defendo que essa metáfora assume um compromisso ontológico de mesmo nível que sentenças declarativas chamadas "literais", como "João é policial", ou que sentenças metafóricas categóricas em que não ocorrem nomes próprios, como "Meu trabalho é uma prisão". A existência desse tipo de metáfora nos permite concluir que o que distingue os usos literais dos usos metafóricos da linguagem não é essencialmente um descompromisso dos últimos com a verdade, mas uma transgressão, por parte dos mesmos, daquilo que é canonicamente estabelecido.

As elucidações feitas acima podem nos render ainda uma considerável reformulação da tese de Glucksberg e Keysar. Como vimos, os autores sustentam que as metáforas categóricas sempre operam de modo a originar categorias de ordem superior (superordinate categories). Mas vejamos o que se passa se trabalharmos com uma variação da metáfora judaica. Mantenhamos o domínio-fonte intacto, porém, ao invés de trabalharmos com um domínio-alvo individual, trabalhemos com um nome de categoria no domínio-alvo e com a negação. Uma metáfora como "Alguns nazistas não são Demjanjuks" não produz uma categoria de ordem superior. Ao invés de aumentar a extensão da categoria do domínio-fonte acrescentando-Ihe um ou mais elementos, o enfoque recai sobre aquela parcela da categoria dos nazistas que não faz qualquer intersecção com a categoria dos Demjanjuks. Sendo a categoria dos nazistas A e a dos Demjanjuks B, a categoria formada pela metáfora é a da subtração $A-B$ ou $A-(A \cap B)$ e, portanto, se o enunciado é verdadeiro, trata-se de uma categoria de ordem igual ou inferior à categoria do domínio-alvo em termos de extensão. Caso haja nazistas que são Demjanjuks, então, a nova categoria é inferior e, pode-se dizer, uma sofisticação das categorias anteriores. Poder-se-ia falar em "nazistas Demjanjuks" e "nazistas não-Demjanjuks". Com essas considerações, quero deixar explícito que metáforas categóricas não apenas podem operar ampliando a extensão de conceitos como também podem operar no sentido oposto, refinando ou sofisticando um conceito. 
Em artigos recentes tenho defendido a tese de que proposições filosóficas como "Uma imagem nos mantinha presos"16 (WITTGENSTEIN, 2006, \$115) e "O pensar é um ouvir e um

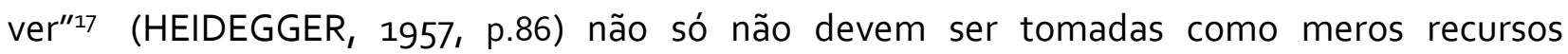
ornamentais como não devem tampouco ser tomadas como proposições que apresentam algo como um significado de segunda ordem ${ }^{18}$. Para usar a boa expressão de Goodman, elas são "erros-categoria calculados" (GOODMAN, 1976, p.73) que têm por fim o abalo efetivo de um certo paradigma categorial. Desse modo, seu emprego não é estilístico ou mesmo contingente - é incontornável. Trata-se de preencher uma lacuna semântica tendo-se em vista uma disputa acerca do melhor modo de descrever os fatos ${ }^{19}$. Mas, se, por um lado, a natureza assertórica das descrições e definições metafóricas em nada se difere da natureza assertórica das descrições e definições mais habituais ou canônicas, por outro lado, seguem merecendo o nome de "metáforas", na medida em que têm a marca do desvio com relação aos usos correntes e um modo peculiar de selecionar os aspectos relevantes de seus objetos.

\section{Conclusão}

Vejamos o que se pode concluir, após esse exame de exemplos ofertados por expoentes da inovação semântica via metáfora, das diferenças entre metáforas analógicas e metáforas categóricas. Em resumo, afirmo que a distinção entre o tradicional modelo analógico (que remonta a Aristóteles, mas ecoa no Princípio de Invariância, de Lakoff) e o modelo categórico (ou "de inclusão em classe") proposto por Glucksberg e Keysar, no que diz respeito à ocorrência de nomes próprios na posição de domínio-fonte, pode se dar com base nos seguintes critérios:

\footnotetext{
16 "Ein Bild hielt uns gefangen".

17 "Das Denken ein Hören und ein Sehen ist" .

18 Como querem sustentar Searle e Ricoeur em suas teorias da metáfora.

19 Por essa perspectiva, metáforas como as de Wittgenstein têm, por um lado, traços de catacrese, reivindicando mudanças efetivas da extensão de certos termos para fins de preenchimento de lacuna semântica. Mas, por outro lado, longe de se deixarem reduzir a tropos lexicalizados ou mortos, apresentam um caráter assertórico que só pode se dar mediante a impertinência ou transgressão de regras canônicas, não se enquadrando na categoria dos tropos que visam apresentar uma única ideia "toda nua e sem disfarce" (FONTANIER, 1977, p. 219).
} 
1) A ocorrência de um artigo indefinido antes do nome próprio que expressa um domínio-fonte é marca distintiva das metáforas categóricas. Mas trata-se de um critério limitado, que está longe de abarcar todos os casos de metáforas categóricas em que ocorrem nomes próprios na posição de domínio-fonte.

2) Metáforas analógicas em que ocorrem nomes próprios no domínio-fonte admitem paráfrases na forma de símile (com o acréscimo da partícula comparativa "como" sem perda de conteúdo cognitivo). Isso se dá por conta da grande impertinência ontológica da igualdade que estabelecem (no caso das metáforas afirmativas). A transformação em símile se mostra um meio de mitigar a asserção, deixando claro que não se trata de uma relação de igualdade (de referências) e sim de semelhança. Vimos que outros recursos - tais como a exposição, no proferimento, de mais um termo da relação analógica -, podem desempenhar essa função de mitigar o compromisso ontológico. O mesmo não se dá com metáforas afirmativas categóricas. Se digo "Jeová é como um Rothschild" não dou a entender que Jeová pertence à classe dos Rothschilds, mas que Ele se parece com um ente singular que pertence a essa classe. Ou seja, a inserção do "como" altera o sentido da proposição.

3) Em metáforas categóricas, o nome próprio de um indivíduo singular, quando ocorre na posição de domínio-fonte, pode aparecer no plural, mantendo sua referência ao indivíduo, mas somando a ela uma referência a uma classe de indivíduos. O mesmo não se aplica à metáfora analógica, na qual os nomes próprios no singular mantêm sua referência a um indivíduo singular.

4) Se, mesmo estando no singular, o nome próprio que expressa o domínio-fonte de uma metáfora apresenta dois referentes simultaneamente (um indivíduo singular e uma classe), então, não se pode ver aí uma metáfora analógica.

5) Metáforas categóricas estabelecem novas categorias para preencher lacunas semânticas e o fazem explicitando um nome de indivíduo (ou espécie) prototípico(a) no domínio-fonte. A 
composição de metáforas analógicas não está condicionada pela detecção de tais nomes, bastando, para o sucesso das mesmas, a determinação da semelhança entre dois objetos a partir da exposição das relações proporcionalmente idênticas que os mesmos guardam com outro par de objetos.

6) As metáforas categóricas podem ser sofisticadas mediante a presença de termos de gradação. Termos como "meio", "muito", "pouco", "bastante", "totalmente" etc. permitem a elaboração da relação de instanciação estabelecida nesse tipo de metáfora. Tais termos permitem expressar a estrutura graduada dos conceitos constituídos com base em protótipos, os quais são as bases das metáforas categóricas. Analogias não permitem a exploração das estruturas graduadas, uma vez que se fundam em identidades de relação. Não se pode falar em mais idêntico ou menos idêntico.

Feita a revisão dos critérios de distinção estabelecidos neste trabalho, perguntemos: o que se ganha, no tocante à compreensão de como nomes próprios funcionam em metáforas, com essa distinção entre o modelo analógico e modelo categórico? Primeiramente, abre-se espaço para um estudo mais apropriado de metáforas ad hoc e para a inventividade poética que, como eu já havia exposto em meu artigo anterior, se via constrangida pelos rígidos limites impostos pela Teoria da Metáfora Conceitual conforme concebida por Lakoff e Johnson. Em segundo lugar, essa distinção nos permite uma compreensão da veemência ontológica de certas metáforas, as quais atingem o grau máximo de assertividade de uma sentença declarativa. Tais metáforas transgridem os usos canônicos e barganham significado, como fica mais explícito por ocasião de sua ocorrência em textos filosóficos e científicos.

Não há dúvidas de que as metáforas sempre foram e seguem sendo artifícios poéticos e retóricos ímpares no que diz respeito à ornamentação do discurso, mas, no presente trabalho, ocupei-me em sublinhar uma face mais descritiva e cognitiva das mesmas. Espero ter delineado suficientemente bem essa forma de categorizar que é própria, exclusiva da metáfora. Uma forma de categorizar que só pode se dar mediante a impertinência calculada (significativa) e a um modo peculiar de fazer a seleção dos aspectos relevantes do objeto descrito. A 
transgressão dos usos canônicos de modo a efetuar redimensionamentos da extensão de nossos conceitos, longe de ser um capricho de literato, é um expediente de transformação das línguas.

No que diz respeito às contribuições desse trabalho para o estabelecimento de uma teoria da metáfora, gostaria de dizer algumas palavras: se, de fato, as considerações feitas acima sobre metáforas categóricas procedem, então, surgem problemas consideráveis para certas concepções de metáfora como aquela desenvolvida por Searle - a qual pressupõe que, para que se possa compreender o significado de metáforas na forma "S é P", precisamos recorrer a paráfrases na forma "S é $\mathrm{R}$ ", onde $\mathrm{R}$ é o predicado literal que substitui $\mathrm{P}$ - e como aquela desenvolvida por Davidson - a qual trata toda sentença metafórica como sentença de identidade e que, por essa razão, tende a afirmar que as mesmas são, na sua grande maioria e no que diz respeito à sua função referencial, falsidades patentes.

É preciso fazer ainda uma desambiguação que pode evitar sérias confusões. Há uma figura de linguagem marcada tanto pela transformação de nomes próprios em nomes comuns, i.e., nomes de classes quanto pela operação inversa. O nome de tal figura é "antonomásia". Littré define a antonomásia como "uma espécie de sinédoque que consiste em tomar um nome comum por um nome próprio ou um nome próprio por um nome comum" (LITTRÉ apud PERELMAN; TYTECA, 2010, \$42, p. 235). Na gramática de Bechara, o termo "antonomásia" não aparece, mas vemos a seguinte delineação de uma figura de linguagem com as seguintes características:

Passagem de nomes próprios a comuns. - Não nos prendemos apenas à pessoa ou coisa nomeada; observamos-lhe qualidades e defeitos que se podem transferir a um grupo mais numeroso de seres. Os personagens históricos, artísticos e literários pagam o tributo de sua fama com o desgaste do valor individualizante do seu nome próprio, que por isso, passa a comum. Por esta maneira é que aprendemos a ver no Judas não só o nome de um dos doze apóstolos, aquele que traiu Jesus; é também a encarnação mesma do traidor, do amigo falso, em expressões do tipo: Fulano é um judas. (BECHARA apud MARTINS, 2009, p.118)

A delineação feita pelo gramático concorda somente de modo parcial com a classificação proposta neste artigo. O exemplo do Judas é, certamente, um exemplo de 
metáfora categórica, porém, os casos que consideramos no presente trabalho transbordam essa sistematização por apresentarem as seguintes características: 1) podem se dar ad hoc - no contexto adequado, qualquer nome próprio pode ser usado assim, não apenas os célebres (cujas notas características a se ressaltar já estão prefixadas) e não é um "desgaste do valor individualizante" o que as habilita; 2) podem preencher lacunas semânticas - quando tratamos do estabelecimento (ou evidenciação) de categorias a partir de protótipos não estamos lidando necessariamente com categorias já estabelecidas, como a do "traidor". Pode ser o caso que a categoria simplesmente não tenha um nome ou expressão muito clara em nossos modos canônicos de uso linguagem e que a mesma só encontre uma expressão apropriada na operação metafórica da transferência de nomes. Esse é o caso da metáfora "X é um Peeperkorn".

A crítica apresentada, no presente trabalho, à Teoria da Metáfora Conceitual não é uma crítica que atinja a teoria em sua totalidade. Estou plenamente de acordo com Lakoff e Johnson quanto à afirmação de que a metáfora não é algo de ordem meramente linguística e sim da ordem do pensamento ou quanto à assunção de que "em geral, conceitos metafóricos são definidos não em termos de imagens concretas (voar, engatinhar, descer a rua etc.), mas em termos de categorias mais gerais, como passar" (LAKOFF; JOHNSON, 2003, p.45). Mas notemos, com relação a esse último ponto, que os autores prudentemente lançam mão da expressão "em geral" para tratar da constituição das metáforas conceituais, de modo que deixam aberta uma brecha para casos especiais. Talvez certas metáforas categóricas cuja posição de domínio-fonte é ocupada por um nome próprio possam entrar justamente nessa brecha, afrouxando um pouco os laços excessivamente apertados que os autores estabeleceram entre a formação de metáforas e certa concepção simplória de experiência e de emergência direta. Claro está que, por um lado, a natureza das metáforas que examinamos aqui é predominantemente ad hoc, o que as distancia do posto basilar próprio das metáforas conceituais. Mas, por outro lado, perguntemos: como uma metáfora ad hoc - periférica (ou superficial) no que diz respeito à imagem de mundo vigente em uma comunidade linguística poderia torna-se uma metáfora conceitual, central na constituição dessa imagem de mundo? 
No Sobre a Certeza, Wittgenstein nos oferece apontamentos que podem render bons esclarecimentos sobre o assunto. A ideia do filósofo é que as proposições gramaticais que funcionam como "regras de testagem" (WITTGENSTEIN, 1972, \$98) em determinado jogo de linguagem devem ser aprendidas por meio do engajamento do falante em uma prática, como ocorre com qualquer proposição empírica. Uma metáfora como "Pessoas X são Rothschilds" pode ser proferida em um jogo de linguagem como aquele descrito acima (da conversa entre leitores de A Montanha Mágica) e debatida, corrigida etc. Mas, uma vez que passemos a crer firmemente no que diz o proferimento, e que passemos a tratar indivíduos do tipo $X$, em outras práticas de linguagem, como pertencendo à categoria dos Rothschilds, torna-se, a um só tempo, desnecessário voltar a proferir a metáfora e possível derivar da mesma toda uma rede de metáforas e mesmo de sentenças literais.

Enfim, a ideia de uma rede de metáforas condicionada (em termos de sistematicidade e coerência) por uma metáfora mais fundamental (a metáfora conceitual) me parece muito valiosa e me pergunto se não há meios de torná-la mais compatível com uma concepção mais rigorosa da linguagem (suas inconformidades e disputas) e de experiência (que investigue com mais cuidado o papel da relevância nas seleções de aspectos que fazemos ao estabelecermos categorias). O estudo que agora se encerra é uma investida neste sentido.

\section{Referências Bibliográficas}

ARISTÓTELES. Poetics. Transl. Stephen Halliwell. 2.ed. London: Harvard University Press, 2005 .

. The Art of Rhetoric. Transl. J. H. Freese. London: Harvard University Press, 2000.

BARSALOU, L.W. "Ad hoc categories". Memory \& Cognition, v.11, n.3, pp.211-227, 1983.

BLACK, M. "Metaphor". Proceedings of the Aristotelian Society, New Series, v. 55, pp.273-294, 1955. 
CAMP, E. "Contextualism, Metaphor and What is Said". Mind \& Language, v.21, n.3, p.28o-309, 2006.

DAVIDSON, D. "What Metaphors Mean". Critical Inquiry, v.5, n. 1, Special Issue on Metaphor, pp.31-47,1978.

FONTANIER, P. Les Figures du Discours. Paris: Flammarion, 1977.

GLUCKSBERG, S.; KEYSAR, B. "Understanding Metaphorical Comparisons: Beyond Similarity". Psychological Review, v.97, n.1, pp.3-18, 1990.

GOETHE, J. W. Faust I/II. Leipzig: Insel Verlag, 1998.

GOODMAN, N. Languages of Art: an approach to a Theory of Symbols. Indianapolis: Hackett, 1976.

GRICE, P. "Logic and Conversation". In: Studies in the Ways of Words. London: Harvard, 1991.

HEIDEGGER, M. Der Satz vom Grund. Pfullingen: Günter Neske, 1957.

HUME, D. A Treatise of Human Nature. David F. Norton \& Mary J. Norton (Ed.). New York: Oxford University Press, 2000.

JOHNSON, M (ed). Philosophical Perspectives on Metaphor. Minneapolis: University of Minnesota Press, 2011.

LAKOFF, G.; JOHNSON, M. Metaphors We Live By. Chicago: The University of Chicago Press, 1980.

LAKOFF, G. "The contemporary theory of metaphor". In Ortony, A. (ed.). Metaphor and Thought. Cambridge: Cambridge University Press, pp.202-251, 1993.

MACHADO DE ASSIS. Dom Casmurro. Santiago: Editora Click, 1997.

MANN, T. A Montanha Mágica. Trad.: Herbert Caro. Rio de Janeiro: Nova Fronteira, 1980. Der Zauberberg. Berlin: Fischer Verlag, 1952.

MARTINS, A.L. "Referenciação e nomes próprios modificados". Cadernos do CNFL, v.12, n.12. Rio de Janeiro: CiFEFiL, pp.106-123, 2009.

PERELMAN, C; TYTECA, L. Traité de l'argumentation. Bruxelles: Editions de I'Université de Bruxelles, 2010. 
QUINTILIANO. Institutio Oratoria. Transl. H.E. Butler. Cambridge: Harvard University Press, 1953.

RICHARDS, I.A. The Philosophy of Rhetoric. Oxford: Oxford University Press, 1936.

RICOEUR, P. La Métaphore Vive. Paris: Éditions du Seuil, 1975.

RIEDEL, D.C. Tempo e Metáfora em Machado de Assis. Rio de Janeiro: EdUERJ, 2008.

SEARLE, J. Expression and Meaning: Studies in the Theory of Speech Acts. New York: Cambridge University Press, 2005.

SEMINO, E; STEEN, G. "Metaphor in Literature". In: GIBBS, Jr. R.W. (Ed.). The Cambridge Handbook of Metaphor and Thought. Cambridge : Cambridge University Press, pp. 232-246, 2010.

WEE, L. "Proper names and the theory of metaphor". Journal of Linguistics, v.42, issue 02, pp.355-371, 2006.

WITTGENSTEIN, L. Tractatus Logico-Philosophicus; Tagebücher 1914-1916; Philosophische Untersuchungen. Frankfurt am Main: Suhrkamp, 2006.

On Certainty. Trad. Denis Paul e G.E. Anscombe. New York: Harper \& Row, publishers, 1972.

ZIR, A. "A tese da primazia da metáfora, defesa e problematização: um estudo a partir de Vico". Linguagem em (Dis)curso - LemD, v. 9, n. 1, p. 107-130, jan./abr. 2009.

i Diogo GURGEL, Prof. Dr.

Universidade Federal Fluminense (UFF)

diogo.gurgel@gmail.com

Recebido em 25/04/2015

Aceito em 13/06/2015 